\title{
Perencanaan Ulang Geometrik Dan Perkerasan Jalan Pada Ruas Jalan Batas Kota Padang - Kota Painan KM 70+000 - KM 72+700
}

\author{
Elsa Eka Putri ${ }^{1}$, Muhammad Iqbal ${ }^{2}$ \\ Fakultas Teknik, Universitas Andalas ${ }^{1,2}$ \\ Email: elsaeka@eng.unand.ac.id ${ }^{1}$, moehammad0021@gmail.com ${ }^{2}$ \\ DOI: http://dx.doi.org/10.31869/rtj.v5i1.2813
}

\begin{abstract}
Software bisa membantu pekerjaan menjadi mudah dan cepat. Autodesk Infraworks adalah salah satu software yang dapat mempermudah perencanaan jalan dan merupakan software yang cukup banyak digunakan oleh negara maju. Perencanaan ulang geometrik jalan meliputi perhitungan tebal perkerasan serta anggaran biaya dengan studi kasus pada jalan batas Kota Padang - Kota Painan KM 70+000 - KM 72+700 yang berlokasi di Sago Salido, IV Jurai, Kabupaten Pesisir Selatan, Provinsi Sumatera Barat. Jalan batas Kota Padang - Kota Painan ini merupakan jalur Lintas Sumatra yang menghubungkan antara Provinsi Sumatera Barat dengan Provinsi Bengkulu. Tujuan dari penelitian ini adalah merencanakan ulang geometrik jalan, tebal perkerasan jalan, dan rencana anggaran biaya berdasarkan standar dan peraturan yang berlaku di Indonesia, sehingga dapat bermanfaat sebagai referensi dalam perencanaan jalan dengan menggunakan software Autodesk Infraworks yang disesuaikan dengan peraturan yang berlaku di Indonesia. Perencanaan geometrik jalan menggunakan aplikasi Autodesk infraworks didapatkan hasil untuk jalan kolektor kelas III A ini, sepanjang 2706,38 $\mathrm{m}$ yang memiliki 8 tikungan dan 6 lengkung vertikal serta volume galian sebesar $21550,44 \mathrm{~m}^{3}$ dan volume timbunan sebesar 21519,47 $\mathrm{m}^{3}$. Perhitungan tebal perkerasan dilakukan berdasarkan Manual Desain Perkerasan (MDP) tahun 2017 dengan menggunakan struktur perkerasan kaku sehingga didapatkan struktur perkerasan dengan hasil pelat beton dengan tebal $40 \mathrm{~mm}$, lapis fondasi LMC dengan tebal $60 \mathrm{~mm}$ dan lapis drainase dengan tebal $145 \mathrm{~mm}$. Dari perencanaan jalan ini diperoleh rencana anggaran biaya sebesar Rp. 43.447.698.000,00 (empat puluh tiga milyar empat ratus empat puluh tujuh juta enam ratus sembilan puluh delapan ribu rupiah). Sehingga dapat disimpulkan aplikasi Autodesk Infraworks dinilai dapat mempermudah pelaksanaan dan penggambaran dalam pekerjaan serta menghemat waktu, dengan standar AASHTO (American Association of State Highway and Transportation Officials) tahun 2011 dengan perbedaan hasil perhitungan kecil dari $1 \%$.
\end{abstract}

Keywords: Autodesk Infraworks, Geometrik Jalan, Perkerasan Jalan, Rencana Anggaran Biaya

\section{PENDAHULUAN}

Autodesk Infraworks merupakan salah satu software keluaran Autodesk yang dapat memodelkan, manganalisis, dan memvisualisasikan konsep desain perencanaan. Software ini dinilai dapat mempermudah perencanaan jalan dan merupakan software yang cukup banyak digunakan oleh negara maju.

InfraWorks ini merupakan salah satu software yang banyak digunakan dalam lingkup Building Information Modelling (BIM) untuk desain proyek infrastruktur. InfraWork memungkinkan untuk merencanakan suatu infrastruktur dalam waktu yang singkat dengan hasil yang cukup akurat (PT. Adi Karya, 2020; Syaputra, 2021).

Penelitian ini merupakan perencanaan ulang geometrik jalan menggunakan Autodesk Infraworks dan menghitung tebal perkerasan serta anggaran biaya dengan studi kasus pada jalan batas Kota Padang - Kota Painan KM 70+000 - KM 72+000 yang berlokasi di Sago Salido, IV Jurai, Kabupaten Pesisir Selatan, Provinsi Sumatera Barat. Jalan batas Kota Padang - Kota Painan ini merupakan jalur Lintas Sumatra yang menghubungkan antara Provinsi Sumatera Barat dengan Provinsi Bengkulu. Selanjutnya hasilnya dibandingkan hasil perhitungan manual dengan menggunakan standar Bina Marga. Sehingga bermanfaat sebagai referensi dalam perencanaan jalan dengan menggunakan software Autodesk Infraworks yang disesuaikan dengan peraturan yang berlaku di Indonesia

\section{METODE PENELITIAN}

Perencanaan geometrik jalan dilakukan di ruas jalan batas Kota Padang - Kota Painan pada KM 70+000 hingga KM 72+700 yang berlokasi di Sago Salido, IV Jurai, Kabupaten 
Pesisir Selatan, Provinsi Sumatera Barat. Perencanaan yang dilakukan adalah perencanaan ulang geometrik dan tebal perkerasan jalan serta menghitung anggaran biayanya, dengan menggunakan data sekunder berupa data kontur, data CBR, dan lalu lintas harian rata-rata dari ruas jalan batas kota Padang - kota Painan km 70+000 - km 72+700 yang didapatkan dari Satker Perencanaan dan Pengawasan Jalan Nasional (P2JN) Sumatera Barat.

Penelitian ini juga menggunakan data CBR dan LHR ruas jalan batas Kota Padang Kota Painan yang diperoleh dari PT. WIRA WIDYATAMA selaku konsultan perencana dalam Proyek Pelebaran ruas jalan batas Kota Padang - Kota Painan KM 70+000 - KM $72+700$. Sedangkan gambar perencanaan ruas jalan tersebut dan data kontur daerah Sago Salido didapat dari website DEMNAS dan diolah di software Global Mapper.

Parameter untuk perencanaan geometrik jalan mengacu kepada standar Bina Marga 2017 dan TPGJAK 1997, yang selanjutnya diolah dengan menggunakan aplikasi Autodesk Infraworks. Parameter yang diinputkan seperti panjang maksimal bagian lurus, jari - jari lengkung minimum, panjang lengkung peralihan, jari - jari minimum yang tidak memerlukan peralihan, jarak pandang henti, jarak pandang mendahului, kelandaian vertikal maksimum, panjang minimum lengkung vertical, kecepatan rencana, dan input lainnya berdasarkan dari standar bina marga.

Perencanaan geometrik jalan ini, tidak memperhitungkan kebebasan samping dan pelebaran tikungan dan juga perencanaan ini tidak menghitung pekerjaan jembatan, perencanaan drainase dan jarak penyinaran lampu yang ada.

Jenis perkerasan yang digunakan pada perencanaan ini adalah perkerasan kaku dengan perencanaan tebal perkerasan jalan mengacu kepada Manual Desain Perkerasan (MDP) tahun 2017.

Perhitungan rencana anggaran biaya menggunakan harga satuan yang ditetapkan oleh Dinas Pekerjaan Umum dan Penataan Ruang kota Padang edisi triwulan IV, untuk menghitung pekerjaan perkerasan jalan serta pekerjaan galian dan timbunan. Gambar 1, adalah bagan alir dari penelitian yang dilakukan.

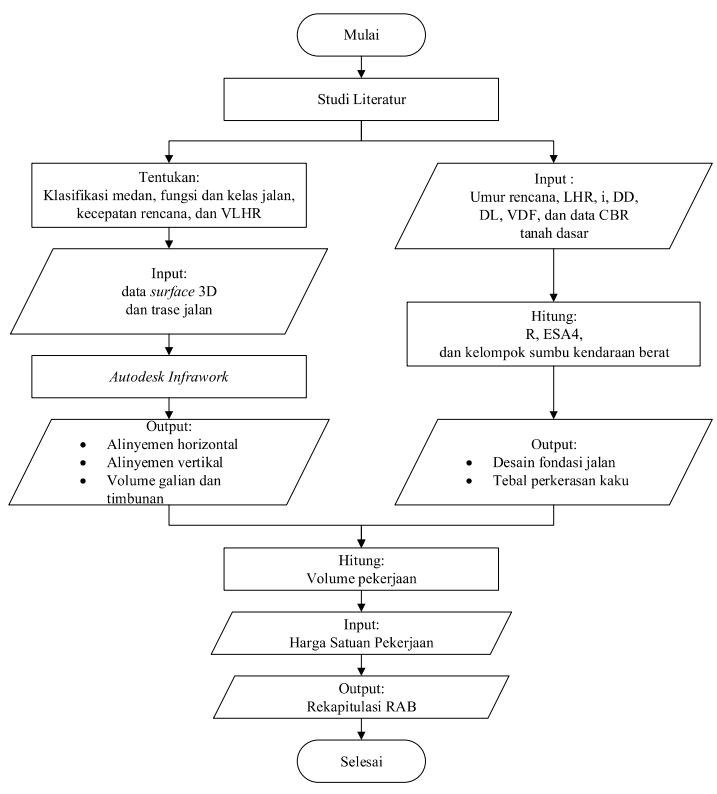

Gambar 1. Bagan Alir Penelitian

\section{HASIL DAN PEMBAHASAN}

Pengklasifikasian medan pada software Autodesk Infraworks diperoleh hasil seperti yang terdapat pada Gambar 2.

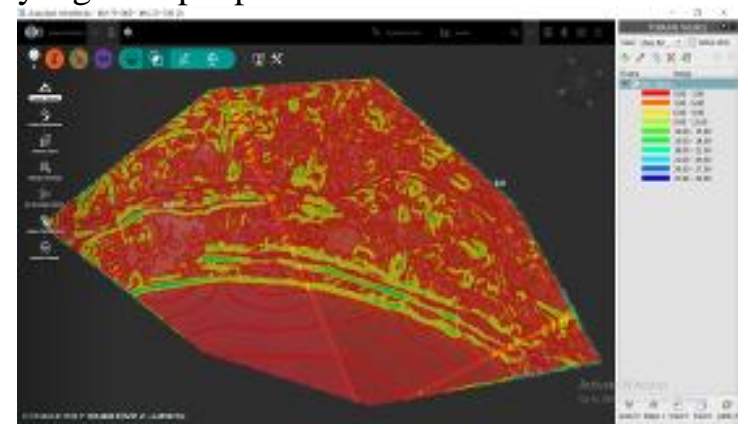

Gambar 2: Klasifikasi Medan

Terlihat pada Gambar 2, bahwa pada peta surface 3D didominasi oleh warna merah, dimana warna merah merupakan warna untuk rentang kemiringan medan $0 \%$ - 3\%. Sehingga dapat diambil kesimpulan bahwa klasifikasi medan pada jalan batas Kota Padang - Kota Painan KM 70+000 - KM 72+700 termasuk pada medan datar (Bina Marga, 2017; Sukirman, 1999)

Selajutnya, pengklasifikasian medan ini juga dilakukan dengan bantuan Autocad Civil $3 D$ untuk menambah keakuratannya. Hasil didapatkan adalah kemiringan medan 1,76\%, dimana hasil kemiringan medan ini merupakan kemiringan untuk medan datar.

Volume Lalu Lintas Rencana

Volume lalu lintas rencana (VLHR) pada jalan batas Kota Padang - Kota Painan dihitung berdasarkan data LHR tahun 2017 yang diproyeksikan ke awal tahun rencana 
yaitu tahun 2021 dengan faktor pertumbuhan lalu lintas senilai $1 \%$ berdasarkan data sekunder yang telah diperoleh dari Satker Perencanaan dan Pengawasan Jalan Nasional (P2JN) Sumatera Barat dengan umur rencana yang ditetapkan yaitu 20 tahun. Hasil perhitungan VLHR yang didapatkan yaitu sebesar 37033,081 smp/jam, seperti yang terlihat pada Tabel 1 .

Tabel 1. Perhitungan VLHR

\begin{tabular}{|c|c|c|c|c|c|}
\hline $\begin{array}{c}\text { Golongan / } \\
\text { Kelompok }\end{array}$ & Jenis Kendaraan & $\begin{array}{c}\text { LHR } \\
2017\end{array}$ & $\begin{array}{c}\text { LHR } \\
2021\end{array}$ & emp & VLHR \\
\hline 1 & $\begin{array}{c}\text { Sepeda motor, sekuter, sepeda kumbang } \\
\text { dan kendaraan bermotor roda 3 }\end{array}$ & 8341 & 8680 & 1 & 10590,857 \\
\hline 2 & Sedan, jeep, dan station wagon & 4197 & 4367 & 1 & 5329,076 \\
\hline 3 & $\begin{array}{c}\text { Opelet, pick-up opelet, sub urban }, \\
\text { combi dan minibus }\end{array}$ & 3484 & 3625 & 2 & 8847,511 \\
\hline 4 & $\begin{array}{c}\text { Pick-up, micro truck dan mobil } \\
\text { hantaran atau pick-up box }\end{array}$ & 2559 & 2663 & 2 & 6498,502 \\
\hline $5 \mathrm{a}$ & Bus kecil & 218 & 227 & 2 & 553,604 \\
\hline $5 \mathrm{~b}$ & Bus besar & 37 & 39 & 3 & 140,941 \\
\hline $6 \mathrm{a}$ & Truk 2 sumbu 4 roda & 293 & 305 & 3 & 1116,097 \\
\hline 6b & Truk 2 sumbu 6 roda & 572 & 595 & 3 & 2178,865 \\
\hline $7 \mathrm{a}$ & Truk 3 sumbu & 267 & 278 & 5 & 1695,096 \\
\hline $7 \mathrm{~b}$ & Truk gandengan & 13 & 14 & 5 & 82,533 \\
\hline $7 \mathrm{c}$ & Truk semi trailer & 0 & 0 & 5 & 0,000 \\
\hline 8 & Kendaraan tidak bermotor & 0 & 0 & 1 & 0,000 \\
\hline & Total & & & 37033,081 \\
\hline
\end{tabular}

\section{Fungsi dan Kelas Jalan}

Berdasarkan Keputusan Mentri Pekerjaan Umum Dan Perumahan Rakyat tahun 2015 tentang penetapan ruas jalan dalam jaringan jalan primer menurut fungsinya sebagai jalan arteri (JAP) dan jalan kolektor - 1 (JKP - 1), jalan batas Kota Padang - Kota Painan merupakan jalan kolektor, dan berdasarkan Keputusan Mentri Perhubungan tahun 2000 tentang penetapan kelas jalan di pulau Sumatera jalan batas Kota Padang - Kota Painan merupakan jalan kolektor kelas III A.

\section{Kecepatan Rencana}

Karena jalan batas Kota Padang - Kota Painan berfungsi sebagai jalan kolektor dan memiliki medan yang datar, maka kecepatan rencana yang digunakan pada perencanaan jalan batas Kota Padang - Kota Painan KM 70+000 - KM 72+700 yaitu 60 km/jam (Bina Marga, 2018).

Penampang Melintang

Berdasarkan TPGJAK 1997, jalur lalu lintas pada jalan batas Kota Padang - Kota Painan KM 70+000 - KM 72+700 adalah tipe 2 jalur - 4 lajur - 2 arah (4/2 B) yang masingmasing jalur memiliki lebar $7 \mathrm{~m}$ dan bahu jalan dengan lebar $2 \mathrm{~m}$. Untuk kemiringan normal alinemen lurus pada lajur jalan, direncanakan $2 \%$ karena perkerasan yang direncanakan pada penelitian ini adalah perkerasan kaku, dan bentuk median yang digunakan pada perencanaan ini adalah median ditinggikan dengan lebar $2 \mathrm{~m}$.

\section{Alinemen Horizontal}

Perencanaan trase jalan batas Kota Padang - Kota Painan KM 70+000 - KM 72+700 didasarkan kepada data perencanaan yang didapatkan dari Satker P2JN dengan koordinat titik awal dan titik akhir serta koordinat PI sebagai berikut:

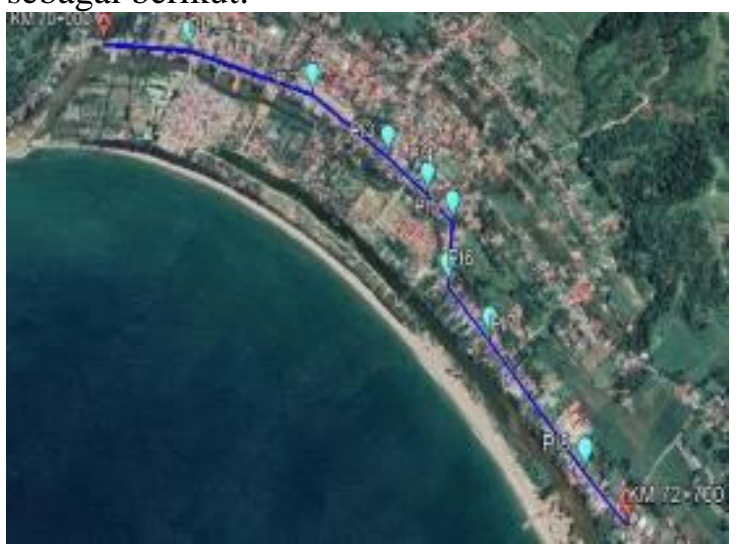

Gambar 3. Trase jalan lama

Data koordinat dari titik-titik pada Gambar 3 adalah sebagai berikut:

- $\quad$ Titik awal : 671233,66; 9855598,69

- PI1 : 671583,86; 9855573,65

- PI2 : 672089,52; 9855409,10

- PI3 : 672389,71; 9855181,73

- PI4 : 672540,92; 9855050,81

- PI5 : 672632,74; 9854954,82

- PI6 : 672605,93; 9854749,74

- $\quad$ PI7 : 672751,21; 9854576,45

- PI8 : 673060,51; 9854190,37

- $\quad$ Titik akhir : 673190,59; 9854049,01

Namun setelah dilakukan perencanaan dengan software Autodesk Infraworks, tikungan pada PI6 memerlukan jari-jari tikungan yang kecil, sehingga perlu digunakan tikungan SS (spiral spiral), sedangkan tikungan SS tidak dapat diaplikasikan pada Autodesk Infraworks, karena pada Autodesk Infraworks hanya bisa menggunakan tikungan FC (full circle) dan SCS (spiral circle spiral) sehingga dilakukan perubahan koordinat PI6 menjadi 672598,04; 9854717,28.

Jalan yang direncanakan memiliki panjang $2706,381 \mathrm{~m}$, yang dimulai dari Sta 00+000 m dan berakhir pada Sta 2+706,381 m seperti yang terdapat pada Gambar 4 


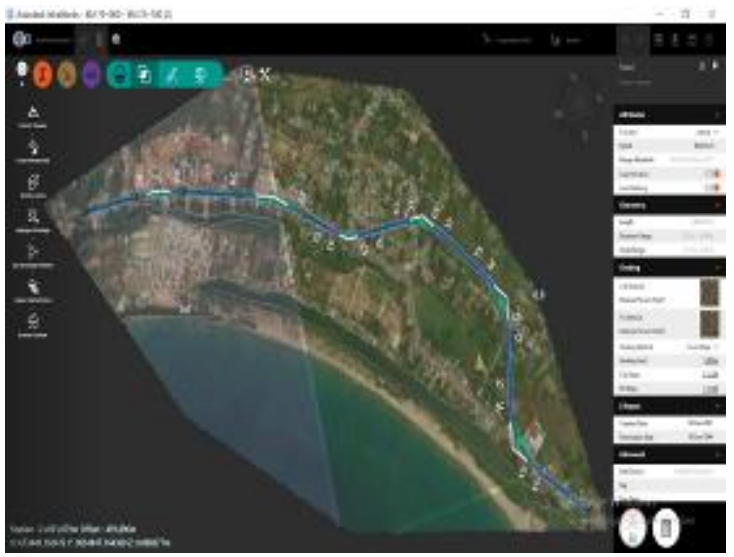

Gambar 4. Trase jalan baru

\section{Perencanaan Tikungan}

Tikungan pada jalan batas Kota Padang Kota Painan KM 70+000 - KM 72+700 direncanakan ulang dengan bantuan software Autodesk Infraworks. Hasil perencanaan didapatkan 2 macam tikungan yaitu 6 tikungan full circle (FC) pada PI1, PI2, PI3, PI4, PI7, dan PI8 dengan jari-jari tikungan $500 \mathrm{~m}$ serta 2 tikungan spiral circle spiral (SCS) pada PI5, dan PI6.dengan jari-jari $110 \mathrm{~m}$ dan panjang lengkung peralihan $50 \mathrm{~m}$. Penetapan jari-jari dan lengkung peralihan pada perencanaan ini ditetapkan berdasarkan kecepatan rencana (SSPGJLK, 1990; TPGJAK, 1997).

Hasil perhitungan tikungan oleh software Autodesk Infraworks dapat dilihat tampilannya pada Tabel 2(a) sampai Tabel 2(h)

\begin{tabular}{|c|c|}
\hline Curve Geometry & $\wedge$ \\
\hline Cunve Radius & $500,0 \mathrm{~m}$ \\
\hline Curve Length (L) & $121,614 \mathrm{~m}$ \\
\hline Start Station & $0+289,999 m$ \\
\hline End Station & $0+411,612 \mathrm{~m}$ \\
\hline Advanced Curve Geometry & $\wedge$ \\
\hline Degree of Curve (D) & $3.44^{*}$ \\
\hline Length of Tangent (T) & $61,108 \mathrm{~m}$ \\
\hline Deflection Angle (I) & $13.94^{\circ}$ \\
\hline External Distance $(E)$ & $3,72 \mathrm{~m}$ \\
\hline Long Chord (LC) & $121,314 \mathrm{~m}$ \\
\hline
\end{tabular}

(a) Perhitungan tikungan $1\left(\mathrm{PI}_{1}\right)$

\begin{tabular}{|lr|}
\hline Curve Geometry & $\wedge$ \\
\hline Curve Radius & $500,0 \mathrm{~m}$ \\
\hline Curve Length (L) & $166,801 \mathrm{~m}$ \\
\hline Start Station & $0+798,099 \mathrm{~m}$ \\
\hline End Station & $0+964,901 \mathrm{~m}$ \\
\hline Advanced Curve Geometry \\
\hline Degree of Curve (D) \\
\hline Length of Tangent (T) \\
\hline Deflection Angle (I) \\
\hline External Distance (E) & $84,183 \mathrm{~m}$ \\
\hline Long Chord (LC) & $19,14^{\circ}$ \\
\hline
\end{tabular}

(b) Perhitungan tikungan $2\left(\mathrm{PI}_{2}\right)$

\begin{tabular}{|c|c|}
\hline Curve Geometry & $\wedge$ \\
\hline Curve Radius & $500,0 \mathrm{~m}$ \\
\hline Curve Length (L) & $32,715 \mathrm{~m}$ \\
\hline Start Station & $1+240,940 \mathrm{~m}$ \\
\hline End Station & $1+273,654 m$ \\
\hline Advanced Curve Geometry & $\wedge$ \\
\hline Degree of Curve (D) & $3.44^{\prime \prime}$ \\
\hline Length of Tangent (T) & $16,363 \mathrm{~m}$ \\
\hline Deflection Angle (I) & $3.75^{\circ}$ \\
\hline External Distance $(E)$ & $0,268 \mathrm{~m}$ \\
\hline Long Chord (LC) & $32,709 \mathrm{~m}$ \\
\hline \multicolumn{2}{|c|}{ (c) Perhitungan tikungan $3\left(\mathrm{PI}_{3}\right)$} \\
\hline Curve Geometry & $\wedge$ \\
\hline Cunve Radius & $500,0 \mathrm{~m}$ \\
\hline Curve Length (L) & $46,979 \mathrm{~m}$ \\
\hline Start Station & $1+433,809 m$ \\
\hline End Station & $1+480,788 \mathrm{~m}$ \\
\hline Advanced Curve Geometry & $\wedge$ \\
\hline Degree of Curve (D) & $3.44^{\circ}$ \\
\hline Length of Tangent (T) & $23,507 \mathrm{~m}$ \\
\hline Deflection Angle (l) & $5.38^{\circ}$ \\
\hline External Distance $(E)$ & $0,552 \mathrm{~m}$ \\
\hline Long Chord (LC) & $46,961 \mathrm{~m}$ \\
\hline
\end{tabular}

(d) Perhitungan tikungan $4\left(\mathrm{PI}_{4}\right)$ 
Vol. 5 No.1 Januari 2022

Rang Teknik Journal

http://jurnal.umsb.ac.id/index.php/RANGTEKNIKJOURNAL

\begin{tabular}{|c|c|}
\hline Curve Geometry & $\wedge$ \\
\hline Curve Radius & $110,0 \mathrm{~m}$ \\
\hline Curve Length (L) & $49,906 \mathrm{~m}$ \\
\hline Start Station & $1+561,005 \mathrm{~m}$ \\
\hline End Station & $1+610,911 \mathrm{~m}$ \\
\hline Advanced Curve Geometry & $\wedge$ \\
\hline Degree of Curve (D) & $15.63^{\circ}$ \\
\hline Length of Tangent (T) & $25,39 \mathrm{~m}$ \\
\hline Deflection Angle (1) & $25.99^{\circ}$ \\
\hline External Distance (E) & $2,892 \mathrm{~m}$ \\
\hline Long Chord (LC) & $49,479 \mathrm{~m}$ \\
\hline Spiral In Geometry & ^ \\
\hline Spiral In Type & Clothaid \\
\hline Spiral In Length & $50,0 \mathrm{~m}$ \\
\hline Start Station & $1+511,005 \mathrm{~m}$ \\
\hline End Station & $7+561,005 \mathrm{~m}$ \\
\hline A value & 74,162 \\
\hline Spiral Out Geometry & $\wedge$ \\
\hline Spiral Out Type & Clothoid \\
\hline Spiral Out Length & $50,0 \mathrm{~m}$ \\
\hline Start Station & $1+610,911 \mathrm{~m}$ \\
\hline End Station & $1+660,911 \mathrm{~m}$ \\
\hline A value & 74162 \\
\hline
\end{tabular}

(e) Perhitungan tikungan $5\left(\mathrm{PI}_{5}\right)$

\begin{tabular}{|c|c|}
\hline Curve Geometry & $\wedge$ \\
\hline Curve Radius & $110,0 \mathrm{~m}$ \\
\hline Curve Length $(L)$ & $56,959 \mathrm{~m}$ \\
\hline Start Station & $1+788,276 \mathrm{~m}$ \\
\hline End Station & $1+245,235 \mathrm{~m}$ \\
\hline Advanced Curve Geometry & $\wedge$ \\
\hline Degree of Curve (D) & $15.63^{*}$ \\
\hline Length of Tangent (T) & $29,133 \mathrm{~m}$ \\
\hline Deflection Angle (D) & $29.67^{\prime}$ \\
\hline External Distance $(E)$ & $3,793 \mathrm{~m}$ \\
\hline Long Chord (LC) & $56,325 \mathrm{~m}$ \\
\hline Spiral In Geometry & $\wedge$ \\
\hline Spiral In Type & Clothoid \\
\hline Spiral In Length & $50,0 \mathrm{~m}$ \\
\hline Start Station & $1+738,276 \mathrm{~m}$ \\
\hline End Station & $1+788,276 \mathrm{~m}$ \\
\hline A value & 74,162 \\
\hline Spiral Out Geometry & $\wedge$ \\
\hline Spiral Out Type & Clothoid \\
\hline Spiral Out Length & $50,0 \mathrm{~m}$ \\
\hline Start Station & $1+845,235 \mathrm{~m}$ \\
\hline End Station & $1+895,235 m$ \\
\hline A value & 74,162 \\
\hline
\end{tabular}

(f) Perhitungan tikungan $6\left(\mathrm{PI}_{6}\right)$

\begin{tabular}{|lr|}
\hline \multicolumn{2}{|l|}{ Curve Geometry } \\
\hline Curve Radius & $500,0 \mathrm{~m}$ \\
Curve Length (L) & $75,931 \mathrm{~m}$ \\
\hline Start Station & $1+981,674 \mathrm{~m}$ \\
End Station & $2+057,606 \mathrm{~m}$ \\
\hline Advanced Curve Geometry \\
\hline $\begin{array}{l}\text { Degree of Curve (D) } \\
\text { Length of Tangent (T) } \\
\text { Deflection Angle (I) } \\
\text { External Distance (E) } \\
\text { Long Chord (LC) }\end{array}$ \\
\hline
\end{tabular}

(g) Perhitungan tikungan $7\left(\mathrm{PI}_{7}\right)$ 
Vol. 5 No.1 Januari 2022

http://jurnal.umsb.ac.id/index.php/RANGTEKNIKJOURNAL

\begin{tabular}{|c|c|}
\hline Curve Geometry & $\wedge$ \\
\hline Curve Radius & $500,0 \mathrm{~m}$ \\
\hline Curve Length (L) & $34,212 \mathrm{~m}$ \\
\hline Start Station & $2+497,172 \mathrm{~m}$ \\
\hline End Station & $2+531,383 \mathrm{~m}$ \\
\hline Advanced Curve Geometry & $\wedge$ \\
\hline Degree of Curve (D) & $3.44^{*}$ \\
\hline Length of Tangent (T) & $17,113 \mathrm{~m}$ \\
\hline Deflection Angle (I) & $3.92^{\circ}$ \\
\hline External Distance $(\mathrm{E})$ & $0,293 \mathrm{~m}$ \\
\hline Long Chord (LC) & $34,205 \mathrm{~m}$ \\
\hline
\end{tabular}

(h) Perhitungan tikungan $8\left(\mathrm{PI}_{8}\right)$

Perhitungan dan perencanaan dengan Autodesk Infraworks ini di validasi dengan perhitungan manual berdasarkan perhitungan Bina Marga 2018. Perhitungan yang diperoleh dengan software Autodesk Infraworks ini kemudian dibandingkan dengan hasil perhitungan manual, dan dapat disimpulkan bahwa perhitungan untuk tikungan FC maupun SCS pada Autodesk Infraworks tidak jauh berbeda dengan hasil perhitungan manual, seperti yang terlihat pada pada Tabel 3 dan 4 .

Tabel 3 Perhitungan Tikungan 1 (FC)

\begin{tabular}{|c|c|c|c|c|}
\hline \multicolumn{5}{|c|}{ Input data } \\
\hline & $\mathrm{Rc}$ & \multicolumn{3}{|c|}{500} \\
\hline & VR & \multicolumn{3}{|c|}{60} \\
\hline & $\Delta \mathrm{PI}$ & \multicolumn{3}{|c|}{13,94} \\
\hline \multicolumn{5}{|c|}{ Output data } \\
\hline \multicolumn{3}{|c|}{ Manual } & Infraworks & Kesimpulan \\
\hline $\mathrm{Tc}$ & $\mathrm{Rc} \times \tan (\Delta \mathrm{PI} / 2)$ & 61,127 & 61,108 & beda 0,019 \\
\hline Ec & $\mathrm{Tc} \times \tan (\Delta \mathrm{PI} / 4)$ & 3,723 & 3,72 & beda 0,003 \\
\hline $\mathrm{Lc}$ & $(\Delta \mathrm{PI} / 360) \times 2 \pi \times \mathrm{Rc}$ & 121,649 & 121,314 & beda 0,335 \\
\hline
\end{tabular}

Tabel 4 Perhitungan Tikungan 5 (SCS)

\begin{tabular}{|c|c|c|c|c|}
\hline \multicolumn{5}{|c|}{ Input data } \\
\hline & $\mathrm{Rc}$ & \multicolumn{3}{|c|}{110} \\
\hline & VR & \multicolumn{3}{|c|}{60} \\
\hline & $\Delta \mathrm{PI}$ & \multicolumn{3}{|c|}{29,67} \\
\hline & Ls & & 50 & \\
\hline \multicolumn{5}{|c|}{ Output data } \\
\hline \multicolumn{3}{|c|}{ Manual } & Infraworks & Kesimpulan \\
\hline $\mathrm{Tc}$ & $\mathrm{Rc} \times \tan (\Delta \mathrm{PI} / 2)$ & 29,135 & 29,133 & beda 0,002 \\
\hline Ec & $\mathrm{Tc} \times \tan (\Delta \mathrm{PI} / 4)$ & 3,793 & 3,793 & sama \\
\hline $\mathrm{Lc}$ & $(\Delta \mathrm{PI} / 360) \times 2 \pi \times \mathrm{Rc}$ & 56,962 & 56,325 & beda 0,637 \\
\hline
\end{tabular}

1.1 Alinemen Vertikal

Alinemen vertikal pada perencanaan ini direncanakan ulang sehingga memiliki 6 PVI yaitu 2 lengkung vertikal cekung dan 4 lengkung vertikal cembung. Panjang lengkung vertikal yang digunakan adalah $40 \mathrm{~m}$. Desain perencanaan alinemen vertikal dapat dilihat pada Gambar 5 hingga Gambar 10.

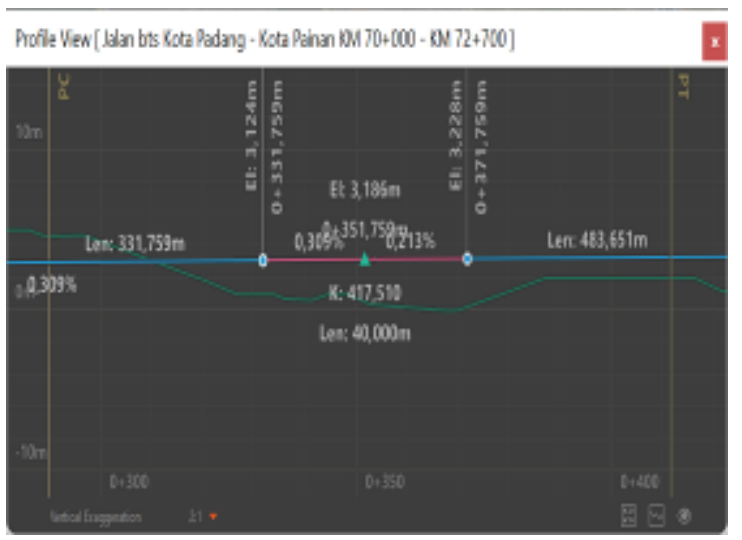

Gambar 5 Desain $\mathrm{PVI}_{1}$

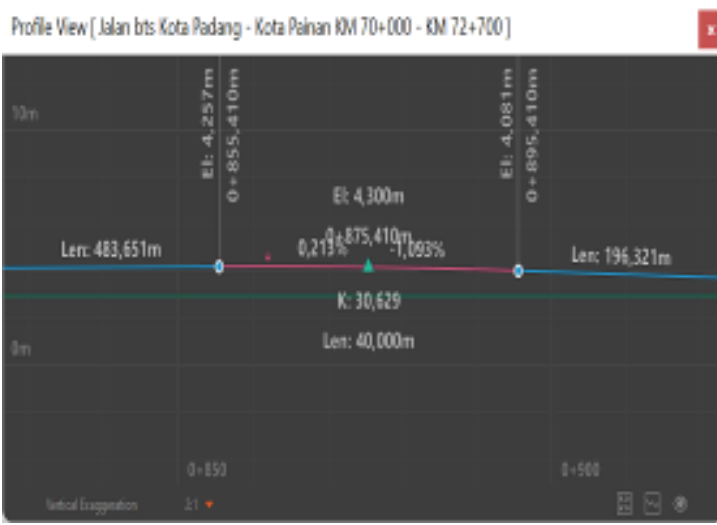

Gambar 6. Desain $\mathrm{PVI}_{2}$

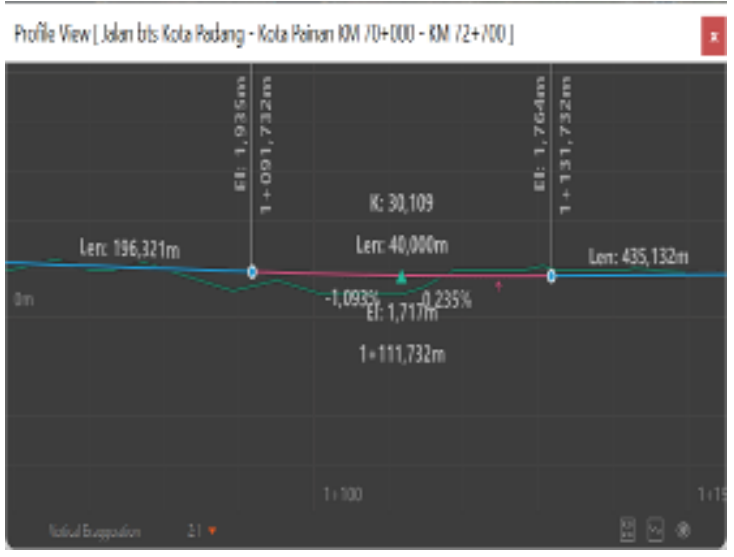

Gambar 7. Desain $\mathrm{PVI}_{3}$

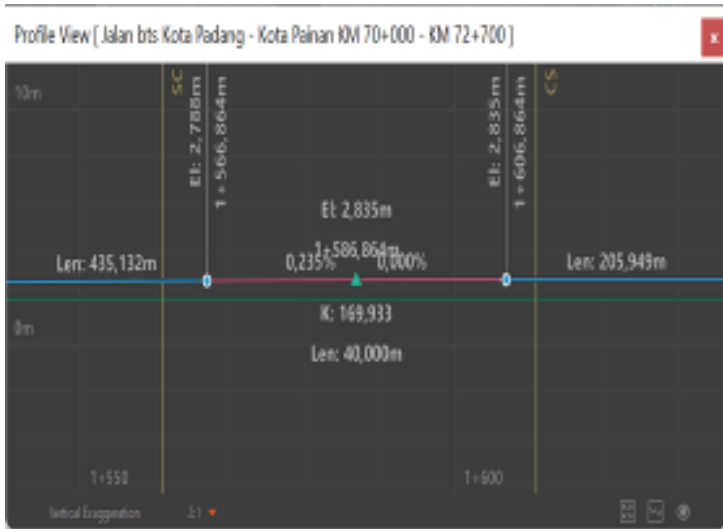

Gambar 8. Desain $\mathrm{PVI}_{4}$ 


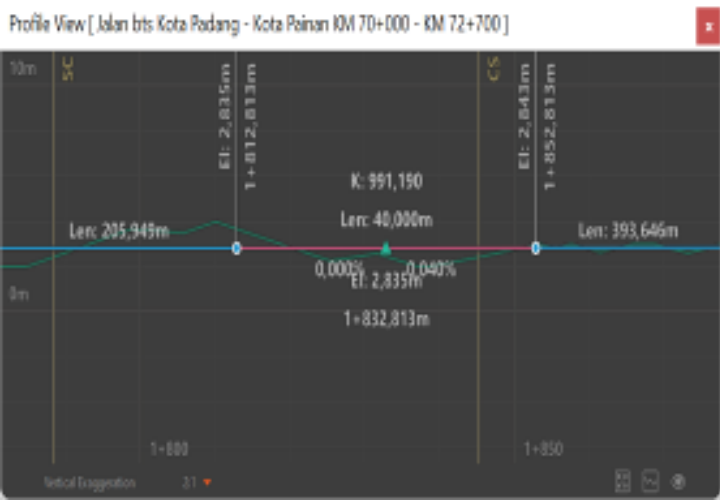

Gambar 9. Desain $\mathrm{PVI}_{5}$

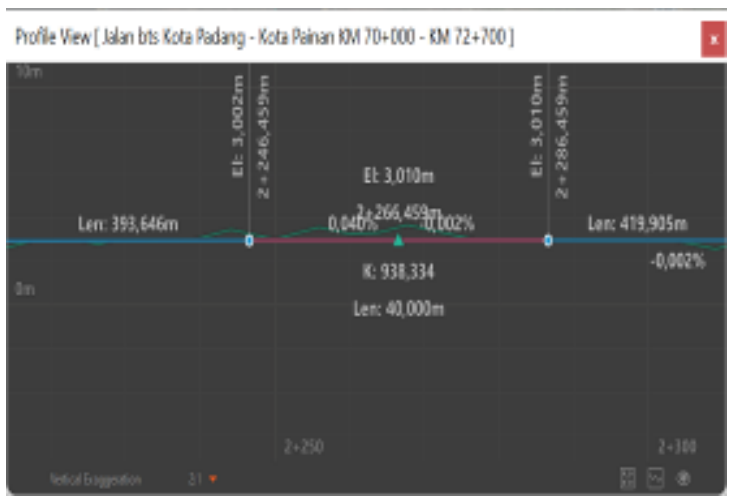

Gambar 10. Desain PVI6

\section{Galian dan Timbunan}

Perhitungan galian dan timbunan dihitung secara otomatis oleh software Autodesk Infraworks dengan volume galian sebesar $21550,438 \mathrm{~m}^{3}$ dan volume timbunan sebesar $21519,470 \mathrm{~m}^{3}$, sehingga didapatkan volume galian lebih besar dari volume timbunan dengan selisih sebesar $30,967 \mathrm{~m}^{3}$ seperti yang terdapat pada Gambar 11.

\begin{tabular}{|c|c|}
\hline Earthwork Quantities & 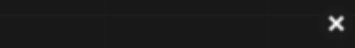 \\
\hline Jalan bts Kota Padan & Kota Painan KM 70+000 - K \\
\hline Station Range: $\quad 0+000,000$ & $2+706,381$ \\
\hline Cut & $21550.438 \mathrm{~m} 3$ \\
\hline Fill & $21519.470 \mathrm{~m} 3$ \\
\hline Net Cut & $30.967 \mathrm{~m} 3$ \\
\hline
\end{tabular}

\section{Perkerasan Jalan}

Jenis perkerasan jalan yang digunakan adalah perkerasan kaku, sehingga umur rencana yang direncanakan yaitu 40 tahun.

Analisis lalu lintas pada perencanaan perkerasan menggunakan MDP terdiri dari:

\section{Lalu lintas harian}

Data lalu lintas harian (LHR) yang digunakan dalam perencanaan perkerasan ini menggunakan data hasil survey tahun 2017 yang diperoleh dari Satker P2JN dengan data yang dapat dilihat pada Tabel 5 .

Tabel 5. Data LHR 2017

\begin{tabular}{|c|c|c|}
\hline $\begin{array}{c}\text { Golongan } / \\
\text { Kelompok }\end{array}$ & Jenis Kendaraan & LHR \\
\hline 1 & Sepeda motor, sekuter, sepeda kumbang dan kendaraan bermotor roda 3 & 8341 \\
\hline 2 & Sedan, jeep, dan station wagon & 4197 \\
\hline 3 & Opelet, pick-up opelet, sub urban, combi dan minibus & 3484 \\
\hline 4 & Pick-up, micro truck dan mobil hantaran atau pick-up box & 2559 \\
\hline $5 \mathrm{a}$ & Bus kecil & 218 \\
\hline $5 \mathrm{~b}$ & Bus besar & 37 \\
\hline $6 \mathrm{a}$ & Truk 2 sumbu 4 roda & 293 \\
\hline 6b & Truk 2 sumbu 6 roda & 572 \\
\hline $7 \mathrm{a}$ & Truk 3 sumbu & 267 \\
\hline $7 \mathrm{~b}$ & Truk gandengan & 13 \\
\hline $7 \mathrm{c}$ & Truk semi trailer & 0 \\
\hline 8 & Kendaraan tidak bermotor & 0 \\
\hline
\end{tabular}

Menghitung faktor pertumbuhan kumulatif dihitung berdasarkan faktor pertumbuhan lalu lintas dan umur rencana sehingga diperoleh faktor pertumbuhan kumulatif (cumulative growth factor) sebesar 48,886 dengan perhitungan sebagai berikut:

$$
\begin{aligned}
\mathrm{R} & =\left((1+0,01 \mathrm{i})^{\wedge} \mathrm{UR}-1\right) / 0,01 \mathrm{i} \\
& =\left((1+0,01(0,01))^{\wedge} 40-1\right) / 0,01(0,01) \\
& =48,886
\end{aligned}
$$

Untuk faktor distribusi lalu lintas pada lajur rencana yang mengacu kepada MDP No. 02/M/BM/2017 dengan hasil ketetapan sebagai berikut:

Faktor distribusi arah (DD): 0,50

Faktor distribusi lajur (DL) : 0,80

\section{Perhitungan Beban Gandar Standar}

Karena data LHR yang didapatkan merupakan data survey pada tahun 2017, maka terlebih dahulu dilakukan perhitungan LHR untuk awal tahun rencana yaitu tahun 2021 berdasarkan laju pertumbuhan lalu lintas. Hasil perhitungan beban gandar standar / Equivalent Standard Axle (ESA4) dapat dilihat pada Tabel 6. 
Tabel 6 Perhitungan beban gandar standar

\begin{tabular}{|c|c|c|c|c|c|}
\multicolumn{7}{|c|}{$($ ESA4) } \\
\hline $\begin{array}{c}\text { Golongan/ } \\
\text { Kelompok }\end{array}$ & LHR 2017 & LHR 2021 & VDF4 normal & $\begin{array}{c}\text { ESA4 } \\
(20 \text { tahun })\end{array}$ & $\begin{array}{c}\text { ESA4 } \\
(40 \text { tahun })\end{array}$ \\
\hline 1 & 8341 & 8679,678 & - & - & - \\
\hline 2 & 4197 & 4367,415 & - & - & - \\
\hline 3 & 3484 & 3625,464 & - & - & - \\
\hline 4 & 2559 & 2662,906 & - & - & - \\
\hline 5a & 218 & 226,852 & - & - & - \\
\hline 5b & 37 & 38,502 & 1 & 123776,371 & 274807,066 \\
\hline 6a & 293 & 304,897 & 0,55 & 539096,275 & 1196896,180 \\
\hline 6b & 572 & 595,225 & 3,4 & 6505953,681 & 14444453,563 \\
\hline 7a & 267 & 277,841 & 5,4 & 4823264,098 & 10708562,910 \\
\hline 7b & 13 & 13,528 & - & - & - \\
\hline 7c & 0 & 0,000 & 7 & 0,000 & 0,000 \\
\hline 8 & 0 & 0,000 & - & - & - \\
\hline \multicolumn{7}{|c|}{ CESA4 } & & 11992090,425 & 26624719,719 \\
\hline
\end{tabular}

\section{Pemilihan Struktur Perkerasan}

Karena hasil perhitungan CESA4 dalam 20 tahun yang diperoleh sebesar $11,99 \times 10^{6}$, maka untuk jenis perkerasan kaku digunakan struktur perkerasan kaku dengan lalu lintas berat diatas tanah dengan $\mathrm{CBR} \geq 2,5 \%$.

\section{Desain Fondasi Jalan}

Berdasarkan data CBR yang telah diperoleh dari satker P2JN, didapatkan nilai CBR tanah dasar pada jalan batas Kota Padang - Kota Painan KM 70+000 - KM 72+700 yaitu 5,62 \% yang dihitung dengan perhitungan sebagai berikut:

$$
\begin{aligned}
& C B R=C B R_{\text {rata-rata }}-f \times \text { deviasi standar } \\
& C B R=7,41-1,282 \times 1,396
\end{aligned}
$$

$C B R=5,62$

Dari nilai CBR tanah dasar ini maka, pada jalan batas Kota Padang - Kota Painan KM 70+000 - KM 72+700 diperlukan perbaikan tanah dasar berupa stabilisasi semen dengan kedalaman $300 \mathrm{~mm}$.

\section{Desain Struktur Perkerasan}

Untuk menentukan desain struktur perkerasan kaku diperlukan perhitungan jumlah kelompok sumbu masing - masing jenis kendaraan dengan umur rencana 40 tahun sehingga didapatkan kumulatif kelompok sumbu kendaraan berat selama umur rencana yaitu $19,73 \times 10^{6}$. perhitungan jumlah kelompok sumbu kendaraan berat dapat dilihat pada Tabel 7.

Tabel 7. Perhitungan kelompok sumbu

\begin{tabular}{|c|c|c|c|c|c|}
\hline $\begin{array}{c}\text { Jenis } \\
\text { Kendaraan }\end{array}$ & $\begin{array}{c}\text { Jumlah } \\
\text { Kelompok } \\
\text { Sumbu }\end{array}$ & LHR 2017 & LHR 2021 & $\begin{array}{c}\text { Kelompok Sumbu } \\
2021\end{array}$ & $\begin{array}{l}\text { Jumlah Kelompok } \\
\text { Sumbu } 2021 \text { - } 2061\end{array}$ \\
\hline $5 \mathrm{~b}$ & 2 & 37 & 38,502 & 77,005 & 549614,132 \\
\hline $6 a$ & 2 & 293 & 304,897 & 609,794 & 4352349,747 \\
\hline $6 \mathrm{~b}$ & 2 & 572 & 595,225 & 1190,451 & 8496737,390 \\
\hline $7 \mathrm{a}$ & 3 & 267 & 277,841 & 833,524 & 5949201,616 \\
\hline $7 \mathrm{~b}$ & 4 & 13 & 13,528 & 54,111 & 386215,336 \\
\hline $7 \mathrm{c}$ & 4 & 0 & 0,000 & 0,000 & 0,000 \\
\hline \multicolumn{5}{|c|}{ Kumulatif kelompok sumbu kendaraan berat 2021 - 2061} & 19734118,221 \\
\hline
\end{tabular}
kendaraan berat

Karena kumulatif kelompok sumbu kendaraan berat desain $19,73 \times 10^{6}$ maka didapatkan struktur perkerasan menggunakan sambungan dowel serta ketebalan lapis perkerasan sebagai berikut:

$\begin{array}{lll}\text { Lapis beton } & : & 285 \mathrm{~mm} \\ \text { Lapis fondasi LMC : } & 100 \mathrm{~mm} \\ \text { Lapis drainase } & : & 150 \mathrm{~mm}\end{array}$

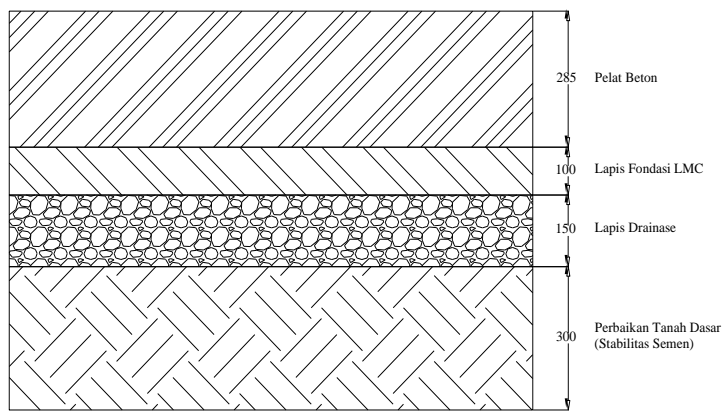

Gambar 12. Desain perkerasan jalan

\section{Rencana Anggaran dan Biaya}

Rencana Anggaran Biaya (RAB) adalah perhitungan banyaknya biaya yang diperlukan untuk bahan dan upah, serta biaya - biaya lain yang berhubungan dengan pelaksanaan proyek tersebut (Ibrahim, 1993). Pembuatan RAB bertujuan untuk mengetahui harga dari setiap item pekerjaan konstruksi, dan menjadi pedoman dalam pengeluaran biaya pada suatu pekerjaan suatu proyek.

Volume Pekerjaan

Uraian perhitungan dan hasil perhitungan volume pekerjaan jalan batas Kota Padang Kota Painan KM 70+000 - KM 72+700 dapat dilihat pada Tabel 8.

Tabel 8. Perhitungan volume pekerjaan 
Vol. 5 No.1 Januari 2022

http://jurnal.umsb.ac.id/index.php/RANGTEKNIKJOURNAL

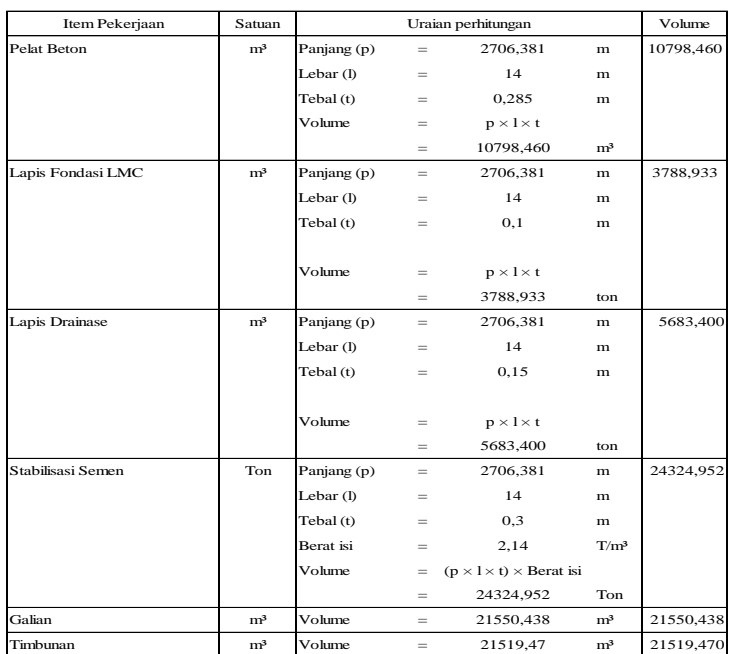

\section{Harga Satuan Pekerjaan}

Harga satuan yang digunakan untuk menghitung harga satuan pekerjaan jalan batas Kota Padang - Kota Painan KM 70+000 - KM $72+700$ didapatkan berdasarkan Daftar Harga Satuan Pekerjaan Bidang ke PU-an dan HSBGN tahun anggaran 2020 edisi triwulan IV yang dikeluarkan oleh Dinas Pekerjaan Umum dan Penataan Ruang Kota Padang pada Oktober 2020. Perhitungan harga satuan pekerjaan dapat dilihat pada Tabel 9 hingga Tabel 14.

Tabel 9. HSP pekerjaan pelat beton

\begin{tabular}{|c|c|c|c|c|c|c|c|c|}
\hline NO. & KOMPONEN & KODE & SATUAN & \begin{tabular}{|l|} 
PERKIRAAN \\
KUANTITAS
\end{tabular} & \multicolumn{2}{|c|}{ HARGA SATUAN } & \multicolumn{2}{|c|}{ JUMLAH HARGA } \\
\hline \multicolumn{9}{|c|}{\begin{tabular}{l|l|} 
A. & TENAGA \\
\end{tabular}} \\
\hline 1. & Pekerja & L01 & jam & 0,5020 & $\mathrm{Rp}$ & $15.000,00$ & $\mathrm{Rp}$ & $7.530,12$ \\
\hline 2. & Mandor & L03 & jam & 0,1004 & $\mathrm{Rp}$ & $25.000,00$ & $\mathrm{Rp}$ & $2.510,04$ \\
\hline \multicolumn{7}{|c|}{ JUMLAH HARGA TENAGA } & $\mathrm{Rp}$ & $10.040,16$ \\
\hline \multicolumn{9}{|c|}{ B. BAHAN } \\
\hline 1 & Semen & M12 & $\mathrm{Kg}$ & 334,7500 & $\mathrm{Rp}$ & $1.247,50$ & Rp & $417.600,63$ \\
\hline 2 & Pasir Beton & M01a & $\mathrm{m}^{3}$ & 0,5163 & $\mathrm{Rp}$ & $179.800,00$ & $\mathrm{Rp}$ & $92.832,60$ \\
\hline 3 & \begin{tabular}{|l} 
Agregat Pecah Mesin 20 - 30 \\
$\operatorname{mm}$ (Agregat Kasar)
\end{tabular} & M93 & $\mathrm{m}^{3}$ & 0,9414 & Rp & $245.400,00$ & $\mathrm{Rp}$ & $231.014,48$ \\
\hline 4 & Air & M170 & $\mathrm{m}^{3}$ & 0,1638 & Rp & $18.100,00$ & Rp & $2.964,24$ \\
\hline 5 & Plasticizer & M171 & $\mathrm{m}^{3}$ & 1,0043 & $\mathrm{Rp}$ & $40.000,00$ & $\mathrm{Rp}$ & $40.170,00$ \\
\hline 6 & Baja Tulangan Polos & M39a & $\mathrm{Kg}$ & 15,8750 & Rp & $12.000,00$ & $\mathrm{Rp}$ & $190.500,00$ \\
\hline 7 & Joint Sealent & M94 & $\mathrm{Kg}$ & 0,9900 & Rp & $37.500,00$ & $\mathrm{Rp}$ & $37.125,00$ \\
\hline 8 & Cat Anti Karat & M95 & $\mathrm{Kg}$ & 0,0200 & Rp & $73.900,00$ & $\mathrm{Rp}$ & $1.478,00$ \\
\hline 99 & Expansion Cap & M96 & $\mathrm{m}^{2}$ & 0,1700 & $\mathrm{Rp}$ & $9.500,00$ & $\mathrm{Rp}$ & $1.615,00$ \\
\hline 10 & Polytene 125 mikron & M97 & $\mathrm{Kg}$ & 0,4375 & $\mathrm{Rp}$ & $23.100,00$ & $\mathrm{Rp}$ & $10.106,25$ \\
\hline 11 & Curing Compound & M98 & Ltr & 0,8700 & $\mathrm{Rp}$ & $46.200,00$ & $\mathrm{Rp}$ & $40.194,00$ \\
\hline \multicolumn{7}{|c|}{ JUMLAH HARGA BAHAN } & $\mathrm{Rp}$ & $1.065 .600,19$ \\
\hline \multicolumn{9}{|c|}{ C. PERALATAN } \\
\hline 1 & Wheel Loader & E15 & jam & 0,0071 & $\mathrm{Rp}$ & $518.040,63$ & $\mathrm{Rp}$ & $3.671,44$ \\
\hline 2 & Concrete Pan Mixer & E43 & jam & 0,0502 & Rp & $733.428,86$ & $\mathrm{Rp}$ & $36.818,72$ \\
\hline 3 & Truck Mixer Agitator & E49 & jam & 0,2382 & $\mathrm{Rp}$ & $729.273,44$ & $\mathrm{Rp}$ & $173.744,98$ \\
\hline 4 & Concrete Paver & E42 & jam & 0,0038 & $\mathrm{Rp}$ & $600.028,40$ & $\mathrm{Rp}$ & $2.295,00$ \\
\hline 5 & Alat Bantu & & Ls & 1,0000 & $\mathrm{Rp}$ & & $\mathrm{Rp}$ & \\
\hline \multicolumn{7}{|c|}{ JUMLAH HARGA PERALATAN } & & $216.530,14$ \\
\hline \multicolumn{7}{|c|}{ D. JUMLAH HARGA TENAGA, BAHAN DAN PERALATAN $(\mathrm{A}+\mathrm{B}+\mathrm{C})$} & & $1.292 .170,50$ \\
\hline \multicolumn{7}{|c|}{\begin{tabular}{l|l} 
E. & OVERHEAD \& PROFIT \\
\end{tabular}} & Rp & $129.217,05$ \\
\hline \multicolumn{7}{|c|}{ F. HARGA SATUAN PEKERJAAN ( + +E) } & $\mathrm{Rp}$ & $1.421 .387,55$ \\
\hline
\end{tabular}

Tabel 10. HSP pekerjaan lapis fondasi LMC

\begin{tabular}{|c|c|c|c|c|c|c|c|c|}
\hline No. & KOMPONEN & KODE & SATUAN & $\begin{array}{l}\text { PERKIRAAN } \\
\text { KUANTITAS }\end{array}$ & HAR & A SATUAN & & AH HARGA \\
\hline A. & TENAGA & & & & & & & \\
\hline 1. & Pekerja & L01 & $\mathrm{jam}$ & 0,4016 & $\mathrm{Rp}$ & $15.000,00$ & $\mathrm{Rp}$ & $6.024,00$ \\
\hline 2. & Mandor & L03 & $\mathrm{jam}$ & 0,1004 & $\mathrm{Rp}$ & $25.000,00$ & $\mathrm{Rp}$ & $2.510,00$ \\
\hline & ILAH HARGA TENAGA & & & & & & $\mathrm{Rp}$ & $8.534,00$ \\
\hline B. & BAHAN & & & & & & & \\
\hline 1 & Semen & M12 & $\mathrm{Kg}$ & 233,8100 & $\mathrm{Rp}$ & $1.247,50$ & $\mathrm{Rp}$ & $291.677,98$ \\
\hline 2 & Pasir Beton & M01a & $\mathrm{m}^{3}$ & 0,5996 & $\mathrm{Rp}$ & $179.800,00$ & $\mathrm{Rp}$ & $107.805,60$ \\
\hline 3 & Agregat Kasar & M03 & $\mathrm{m}^{3}$ & 0,9247 & $\mathrm{Rp}$ & $245.400,00$ & $\mathrm{Rp}$ & $226.927,30$ \\
\hline 4 & Air & M170 & $\mathrm{m}^{3}$ & 0,1638 & $\mathrm{Rp}$ & $18.100,00$ & $\mathrm{Rp}$ & $2.964,24$ \\
\hline 5 & Plasticizer & M171 & $\mathrm{kg}$ & 0,7014 & $\mathrm{Rp}$ & $40.000,00$ & $\mathrm{Rp}$ & $28.057,20$ \\
\hline 6 & Formwork Plate & M195 & $\mathrm{m}^{2}$ & 0,1900 & $\mathrm{Rp}$ & $45.000,00$ & $\mathrm{Rp}$ & $8.550,00$ \\
\hline & LLAH HARGA BAHAN & & & & & & $\mathrm{Rp}$ & $665.982,32$ \\
\hline C. & PERALATAN & & & & & & & \\
\hline 1 & Wheel Loader & E15 & jam & 0,0071 & $\mathrm{Rp}$ & $518.040,63$ & $\mathrm{Rp}$ & $3.671,44$ \\
\hline 2 & Concrete Pan Mixer & E43 & jam & 0,0502 & $\mathrm{Rp}$ & $733.428,86$ & $\mathrm{Rp}$ & $36.818,72$ \\
\hline 3 & Truck Mixer Agitator & E49 & jam & 0,2382 & $\mathrm{Rp}$ & $729.273,44$ & $\mathrm{Rp}$ & $173.744,98$ \\
\hline 4 & $\begin{array}{l}\text { Concrete Vibrator (for } \\
\text { manual) }\end{array}$ & E20 & jam & 0,3012 & & $59.286,90$ & $\mathrm{Rp}$ & $17.857,50$ \\
\hline 5 & Alat Bantu & & Ls & 1,0000 & $\mathrm{Rp}$ & - & $\mathrm{Rp}$ & - \\
\hline & ILAH HARGA PERALATAN & & & & & & $\mathrm{Rp}$ & $232.092,64$ \\
\hline D. & JUMLAH HARGA TENAG & , BAHAI & N DAN PER & RALATAN (A & $+B+$ & & $\mathrm{Rp}$ & $906.608,95$ \\
\hline E. & OVERHEAD \& PROFIT & & & $\% \times \mathrm{D}$ & & & $\mathrm{Rp}$ & $90.660,90$ \\
\hline F. 11 & HARGA SATUAN PEKER & AAN (D & $(+E)$ & & & & $\mathrm{Rp}$ & $997.269,85$ \\
\hline
\end{tabular}

Tabel 11. HSP pekerjaan lapis drainase

\begin{tabular}{|c|c|c|c|c|c|c|c|c|}
\hline \multirow{3}{*}{\begin{tabular}{|l} 
NO. \\
A. \\
1
\end{tabular}} & \multirow[t]{2}{*}{ KOMPONEN } & KODE & \multirow[t]{2}{*}{ SATUAN } & \begin{tabular}{|l|l|} 
PERKIRAAN \\
KUANTITAS \\
\end{tabular} & \multicolumn{2}{|c|}{ HARGA SATUAN } & \multicolumn{2}{|c|}{ JUMLAH HARGA } \\
\hline & & & & & & & & \\
\hline & Pekerja & L01 & $\mathrm{jam}$ & 0,0117 & $\mathrm{Rp}$ & $15.000,00$ & $\mathrm{Rp}$ & 175,50 \\
\hline 2. & Mandor & L03 & jam & 0,0058 & $\mathrm{Rp}$ & $25.000,00$ & $\mathrm{Rp}$ & 145,00 \\
\hline \multicolumn{7}{|c|}{ JUMLAH HARGA TENAGA } & $\mathrm{Rp}$ & 320,50 \\
\hline \multicolumn{9}{|c|}{\begin{tabular}{l|l} 
B. & BAHAN
\end{tabular}} \\
\hline 1 & Lapis Drainase & & $\mathrm{m}^{3}$ & 1,2714 & $\mathrm{Rp}$ & $277.662,49$ & $\mathrm{Rp}$ & $353.028,02$ \\
\hline \multicolumn{7}{|c|}{ JUMLAH HARGA BAHAN } & $\mathrm{Rp}$ & $353.028,02$ \\
\hline \multicolumn{9}{|c|}{\begin{tabular}{|l|l|} 
C. & PERALATAN \\
\end{tabular}} \\
\hline 1 & Wheel Loader & E15 & jam & 0,0086 & $\mathrm{Rp}$ & $518.040,63$ & $\mathrm{Rp}$ & $4.445,69$ \\
\hline 2 & Dump Truck & E09 & jam & 0,1339 & $\mathrm{Rp}$ & $527.898,00$ & $\mathrm{Rp}$ & $70.700,78$ \\
\hline 3 & Motor Grader & El3 & jam & 0,0010 & $\mathrm{Rp}$ & $651.863,52$ & $\mathrm{Rp}$ & 623,97 \\
\hline 4 & Vibratory Roller & E19b & jam & 0,0058 & $\mathrm{Rp}$ & $525.409,07$ & $\mathrm{Rp}$ & $3.069,62$ \\
\hline 5 & Alat Bantu & & Ls & 1,0000 & $\mathrm{Rp}$ & & $\mathrm{Rp}$ & \\
\hline \multicolumn{7}{|c|}{ JUMLAH HARGA PERALATAN } & $\mathrm{Rp}$ & $78.840,06$ \\
\hline \multicolumn{7}{|c|}{\begin{tabular}{|l|l|} 
D. & JUMLAH HARGA TENAGA, BAHAN DAN PERALATAN $(\mathrm{A}+\mathrm{B}+\mathrm{C})$ \\
\end{tabular}} & $\mathrm{Rp}$ & $432.188,58$ \\
\hline \multicolumn{7}{|c|}{\begin{tabular}{l|l} 
E. & OVERHEAD \& PROFIT
\end{tabular}} & $\mathrm{Rp}$ & $43.218,86$ \\
\hline \multicolumn{7}{|c|}{\begin{tabular}{l|l} 
F. & HARGA SATUAN PEKERJAAN $(D+E)$
\end{tabular}} & $\mathrm{Rp}$ & $475.407,44$ \\
\hline
\end{tabular}

Tabel 12. HSP pekerjaan stabilisasi semen

\begin{tabular}{|c|c|c|c|c|c|c|c|c|}
\hline \multirow{3}{*}{ NO. } & \multirow{2}{*}{$\frac{\text { KOMPONEN }}{\text { TENAGA }}$} & KODE & SATUAN & $\begin{array}{l}\text { PERKIRAAN } \\
\text { KUANTITAS }\end{array}$ & \multicolumn{2}{|c|}{ HARGA SATUAN } & \multicolumn{2}{|c|}{ JUMLAH HARGA } \\
\hline & & & & & & & & \\
\hline & Pekerja & L01 & jam & 0,0297 & $\mathrm{Rp}$ & $15.000,00$ & $\mathrm{Rp}$ & 445,50 \\
\hline 2. & Mandor & L03 & jam & 0,0030 & $\mathrm{Rp}$ & $25.000,00$ & $\mathrm{Rp}$ & 75,00 \\
\hline \multicolumn{7}{|c|}{ JUMLAH HARGA TENAGA } & $\mathrm{Rp}$ & 520,50 \\
\hline B. & \multicolumn{8}{|l|}{ BAHAN } \\
\hline 1 & Semen & M12 & $\mathrm{Kg}$ & 56,2380 & $\mathrm{Rp}$ & $1.247,50$ & $\mathrm{Rp}$ & $70.156,91$ \\
\hline 2 & Curing Membrane & M259 & $\mathrm{m}^{2}$ & 2,7111 & $\mathrm{Rp}$ & $200.000,00$ & $\mathrm{Rp}$ & $542.217,67$ \\
\hline \multicolumn{7}{|c|}{ JUMLAH HARGA BAHAN } & $\mathrm{Rp}$ & $612.374,57$ \\
\hline \multicolumn{9}{|c|}{\begin{tabular}{l|l} 
C. & PERALATAN \\
\end{tabular}} \\
\hline 1 & Dump Truck & E09 & Jam & 0,1538 & $\mathrm{Rp}$ & $527.898,00$ & $\mathrm{Rp}$ & $81.175,58$ \\
\hline 2 & Motor Grader & E13 & Jam & 0,0006 & $\mathrm{Rp}$ & $651.863,52$ & $\mathrm{Rp}$ & 415,98 \\
\hline 3 & Watertank Truck & E23 & Jam & 0,0462 & $\mathrm{Rp}$ & $310.558,12$ & $\mathrm{Rp}$ & $14.343,05$ \\
\hline 4 & Pneumatic Tire Roller & E18 & $\mathrm{Jam}$ & 0,0073 & & $548.994,68$ & $\mathrm{Rp}$ & $3.999,63$ \\
\hline 5 & Pulvimixer & E27 & $\mathrm{Jam}$ & 0,0030 & $\mathrm{Rp}$ & $1.512 .640,64$ & $\mathrm{Rp}$ & $4.499,90$ \\
\hline 6 & Alat Bantu & & Ls & 1,0000 & $\mathrm{Rp}$ & & $\mathrm{Rp}$ & \\
\hline \multicolumn{7}{|c|}{ JUMLAH HARGA PERALATAN } & $\mathrm{Rp}$ & $104.434,14$ \\
\hline \multicolumn{7}{|c|}{ D. JUMLAH HARGA TENAGA, BAHA } & $\mathrm{Rp}$ & $717.329,21$ \\
\hline \multicolumn{7}{|c|}{ E. OVERHEAD \& PROFIT } & $\mathrm{Rp}$ & $71.732,92$ \\
\hline \multicolumn{7}{|c|}{$\begin{array}{ll}\text { F. } & \text { HARGA SATUAN PEKERJAAN }(\mathrm{D}+\mathrm{E}) \\
\end{array}$} & $\mathrm{Rp}$ & $789.062,13$ \\
\hline
\end{tabular}

Tabel 13. HSP pekerjaan galian 
Vol. 5 No.1 Januari 2022

http://jurnal.umsb.ac.id/index.php/RANGTEKNIKJOURNAL

\begin{tabular}{|c|c|c|c|c|c|c|c|c|}
\hline NO. & KOMPONEN & KODE & SATUAN & $\begin{array}{l}\text { PERRIRAAN } \\
\text { KUANTITAS }\end{array}$ & \multicolumn{2}{|c|}{ HARGA SATUAN } & \multicolumn{2}{|c|}{ JUMLAH HARGA } \\
\hline \multicolumn{9}{|c|}{ A. TENAGA } \\
\hline 1. & Pekerja & L01 & $\mathrm{jam}$ & 0,0077 & $\mathrm{Rp}$ & $15.000,00$ & $\mathrm{Rp}$ & 115,16 \\
\hline 2. & Mandor & L03 & jam & 0,0038 & $\mathrm{Rp}$ & $25.000,00$ & $\mathrm{Rp}$ & 95,96 \\
\hline \multicolumn{7}{|c|}{ JUMLAH HARGA TENAGA } & $\mathrm{Rp}$ & 211,12 \\
\hline \multirow[t]{2}{*}{ B. } & BAHAN & & & & & & & \\
\hline & & & & & $\mathrm{Rp}$ & - & $\mathrm{Rp}$ & \\
\hline \multicolumn{7}{|c|}{ JUMLAH HARGA BAHAN } & $\mathrm{Rp}$ & \\
\hline \multicolumn{9}{|c|}{ C. PERALATAN } \\
\hline 1 & Excavator & E10 & Jam & 0,0038 & $\mathrm{Rp}$ & $693.466,09$ & $\mathrm{Rp}$ & $2.661,89$ \\
\hline 2 & Dump Truck & E09 & Jam & 0,0333 & $\mathrm{Rp}$ & $527.898,00$ & $\mathrm{Rp}$ & $17.603,60$ \\
\hline 3 & Alat Bantu & & Ls & 1,0000 & $\mathrm{Rp}$ & & $\mathrm{Rp}$ & \\
\hline \multicolumn{7}{|c|}{ JUMLAH HARGA PERALATAN } & $\mathrm{Rp}$ & $20.265,49$ \\
\hline \multicolumn{7}{|c|}{ D. JUMLAH HARGA TENAGA, BAHAN DAN PERALATAN $(\mathrm{A}+\mathrm{B}+\mathrm{C})$} & $\mathrm{Rp}$ & $20.476,61$ \\
\hline \multicolumn{7}{|c|}{ E. OVERHEAD \& PROFIT } & $\mathrm{Rp}$ & $2.047,66$ \\
\hline \multicolumn{7}{|c|}{ F. HARGA SATUAN PEKERJAAN ( $\mathrm{D}+\mathrm{E}$ ) } & $\mathrm{Rp}$ & $22.524,27$ \\
\hline
\end{tabular}

Tabel 14 HSP pekerjaan timbunan

\begin{tabular}{|c|c|c|c|c|c|c|c|c|}
\hline NO. & KOMPONEN & KODE & SATUAN & $\begin{array}{l}\text { PERKIRAAN } \\
\text { KUANTITAS }\end{array}$ & HAR & AA SATUAN & & H HARGA \\
\hline A. & TENAGA & & & & & & & \\
\hline 1. & Pekerja & L01 & $\mathrm{jam}$ & 0,0079 & $\mathrm{Rp}$ & $15.000,00$ & $\mathrm{Rp}$ & 119,05 \\
\hline 2. & Mandor & L03 & jam & 0,0020 & $\mathrm{Rp}$ & $25.000,00$ & $\mathrm{Rp}$ & 49,60 \\
\hline & LAH HARGA TENAGA & & & & & & $\mathrm{Rp}$ & 168,65 \\
\hline B. & BAHAN & & & & & & & \\
\hline & & & & & $\mathrm{Rp}$ & & $\mathrm{Rp}$ & \\
\hline & LAH HARGA BAHAN & & & & & & $\mathrm{Rp}$ & \\
\hline c. & PERALATAN & & & & & & & \\
\hline 1 & Excavator & E15 & Jam & 0,0046 & $\mathrm{Rp}$ & $693.466,09$ & $\mathrm{Rp}$ & $3.194,27$ \\
\hline 2 & Dump Truck & E09 & Jam & 0,1221 & $\mathrm{Rp}$ & $527.898,00$ & $\mathrm{Rp}$ & $64.460,60$ \\
\hline 3 & Motor Grader & El3 & Jam & 0,0020 & $\mathrm{Rp}$ & $651.863,52$ & Rp & $1.293,38$ \\
\hline 4 & Vibratory Roller & El9 & Jam & 0,0042 & $\mathrm{Rp}$ & $525.409,07$ & $\mathrm{Rp}$ & $2.198,00$ \\
\hline 5 & Water tank truck & E23 & Jam & 0,0341 & $\mathrm{Rp}$ & $310.558,12$ & Rp & $10.601,38$ \\
\hline 6 & Alat Bantu & & Ls & 1,0000 & $\mathrm{Rp}$ & - & $\mathrm{Rp}$ & \\
\hline & LAH HARGA PERALATA & & & & & & $\mathrm{Rp}$ & $81.747,63$ \\
\hline D. & JUMLAH HARGA TENA & , BAHA & N DAN PE & RALATAN (A & $+B+$ & & $\mathrm{Rp}$ & $81.916,28$ \\
\hline E. & OVERHEAD \& PROFIT & & & $\% \times D$ & & & $\mathrm{Rp}$ & $8.191,63$ \\
\hline F. & HARGA SATUAN PEKE & AAN $(1$ & $+E)$ & & & & $\mathrm{Rp}$ & $90.107,91$ \\
\hline
\end{tabular}

\section{Bill of Quantity}

Berdasarkan volume pekerjaan dan harga satuan pekerjaan yang telah dihitung sebelumnya didapatkan total Bill of Quantity (BOQ) pekerjaan jalan batas Kota Padang Kota Painan KM 70+000 - KM 72+700 sebesar Rp. 43.447.698.000,00 (empat puluh tiga milyar empat ratus empat puluh tujuh enam ratus sembilan puluh delapan ribu rupiah) dengan perhitungan yang terdapat pada Tabel 15.

Tabel 15. BOQ pekerjaan jalan

\begin{tabular}{|c|c|c|c|c|c|}
\hline Item Pekerjaan & Satuan & \begin{tabular}{|l|} 
Volume \\
\end{tabular} & & HSP & BOQ \\
\hline Pelat Beton & $\mathrm{m}^{3}$ & 10798,460 & & $.421 .387,55$ & $\begin{array}{ll}\mathrm{Rp} & 15.348 .796 .829,54\end{array}$ \\
\hline Lapis Fondasi LMC & $\mathrm{m}^{3}$ & 3788,933 & $\mathrm{Rp}$ & $997.269,85$ & Rp $\quad 3.778 .589 .040,71$ \\
\hline Lapis Drainase & $\mathrm{m}^{3}$ & 5683,400 & $\mathrm{Rp}$ & $475.407,44$ & $\begin{array}{ll}\text { Rp } \quad 2.701 .930 .676,43 \\
\end{array}$ \\
\hline Stabilisasi Semen & Ton & 24324,952 & $\mathrm{Rp}$ & $789.062,13$ & $\begin{array}{ll}\text { Rp } \quad 19.193 .898 .791,62\end{array}$ \\
\hline Galian & $\mathrm{m}^{3}$ & 21550,438 & & $22.524,27$ & $485.407 .850,91$ \\
\hline Timbunan & $\mathrm{m}^{3}$ & 21519,470 & $\mathrm{Rp}$ & $90.107,91$ & $\begin{array}{ll}\text { Rp } & 1.939 .074 .463,25\end{array}$ \\
\hline \multicolumn{5}{|c|}{ Total BOQ } & Rp $43.447 .697 .652,45$ \\
\hline \multicolumn{5}{|c|}{ Dibulatkan Menjadi } & Rp $43.447 .698 .000,00$ \\
\hline
\end{tabular}

\section{PENUTUP}

Berdasarkan dari hasil perhitungan dengan menggunakan data eksisting dari
Satker Perencanaan dan Pengawasan Jalan Nasional (P2JN) Sumatera Barat terdapat perbedaan panjang jalan baru dengan jalan lama, dimana jalan lama memiliki panjang 2,7 $\mathrm{km}$ sedangkan hasil perencanaan ulang ini didapatkan panjang jalan 2,706 km

Pada Perencanaan ulang ini pada perhitungan alinemen horizontal diperoleh tikungan berupa 6 tikungan FC dan 2 tikungan SCS. Sedangkan pada perencanaan alinemen vertikal diperoleh 2 lengkung vertical cekung dan 4 lengkung vertical cembung untuk desain fondasi jalan diperlukan perbaikan tanah dasar berupa stabilisasi semen dengan kedalaman $300 \mathrm{~mm}$

Selanjutnya untuk desain struktur perkerasan didapatkan pelat beton dengan tebal $40 \mathrm{~mm}$, lapis fondasi beton kurus (lean mix concrete) dengan tebal $60 \mathrm{~mm}$ dan lapis drainase dengan tebal $145 \mathrm{~mm}$.

Pada perhitungan RAB didapatkan total BOQ sebesar Rp. 43.447.698.000,00 (empat puluh tiga milyar empat ratus empat puluh tujuh enam ratus sembilan puluh delapan ribu rupiah)

Penggunaan aplikasi Autodesk Infraworks untuk perencanaan geometrik jalan dinilai dapat mempermudah pelaksanaan dan penggambaran dalam pekerjaan serta menghemat waktu

Kekurangan pada Autodesk Infraworks yang ditemukan selama perencanaan ini yaitu pada standar yang digunakan oleh Autodesk Infraworks, karena hanya AASTHO 2011 yang dapat digunakan, sehingga parameter yang ditentukan dan hasil perhitungan yang dihitung secara otomatis pada Autodesk Infraworks mengacu pada AASTHO 2011, maka perlu adanya penyesuaian standar oleh pengguna aplikasi Autodesk Infraworks agar hasil perancanaan sesuai dengan standar yang digunakan di Indonesia.

\section{DAFTAR PUSTAKA}

Autodesk (2021) Elements of the User Interface. Tersedia pada: https://knowledge.autodesk.com/support/inf raworks/learn-

explore/caas/CloudHelp/cloudhelp/ENU/Inf raWorks-UserHelp/files/GUID-

390DEDE6-C26A-45F4-8B16-

23CE3739F9ED-htm.html (Diakses: 1 Juli 2021). 
Bamher, B. G. (2020) Analisis Tebal Perkerasan Lentur Menggunakan Metode Manual Desain Perkerasan Jalan 2017 Pada Proyek Jalan Baru Batas Kota SingarajaMengwitani Buleleng. Universitas Atma Jaya Yogyakarta.

Bina Marga (2017) "Manual Perkerasan Jalan (Revisi Juni 2017),” Jurnal Infrastruktur PUPR. Jakarta.

Bina Marga (2018) "Spesifikasi Umum 2018 Untuk Pekerjaan Jalan dan Jembatan," Surat Edaran Dirjen Bina Marga Nomor 02/SE/Db/2018. Jakarta.

Dimara, I. D. (2017) Perencanaan Geometrik Jalan Dengan Menggunakan AutoCAD Land Dekstop 2009 Pada Ruas Jalan Aminweri - Yendoker Sta 0+000 - Sta 10+500 KM Kabupaten Supiori - Papua. Institut Teknologi Nasional Malang.

Fernanda, M. L. S. (2021) Perencanaan Geometrik Jalan Menggunakan AutoCAD Civil 3d Studi Kasus Jalan Duku - Sicincin Sta 0+000 - Sta 2+700 Provinsi Sumatera Barat. Universitas Andalas.

Ibrahim, Bachtiar. 2001. Rencana dan Estimate Real of Cost. Jakarta: Bumi Aksara.

Manual Desain Perkerasan Jalan (MDP) 2017

Kementerian Pekerjaan Umum Dan Perumahan Rakyat Direktorat Jenderal Bina Marga

Menteri Pekerjaan Umum dan Perumahan Rakyat. 2016. Analisa Harga Satuan Pekerjaan Bidang Pekerjaan Umum No. 28/PRT/M/2016. Jakarta: Kementrian Pekerjaan Umum dan Perumahan Rakyat

Pemerintah Indonesia. 2009. Undang-Undang Republik Indonesia Nomor 22 Tahun 2009 Tentang Tentang Lalu Lintas dan Angkutan Jalan, Jakarta, Sekretariat Negara.

Pemerintah Kota Padang (2020) "Daftar Harga Satuan Pekerjaan Bidang ke PU-an dan HSBGN." Padang: Dinas Pekerjaan Umum dan Penataan Ruang Kota Padang.Bina Marga (1997) Tata Cara Perencanaan Geometrik Jalan Antar Kota. Jakarta.

Pemerintah Republik Indonesia (2006) "Peraturan Pemerintah Republik Indonesia Nomor 34 Tahun 2006 tentang Jalan." Jakarta.

PT. Adhi karya. (2020). Modul Autodesk Civil 3D Basic. Biro Engineering dan BIM.
Geometrik Jalan. Bandung: Nova.

Syaputra, Yogi. 2021. Aplikasi Building Information Modelling (BIM) Pada Perencanaan dan Pemodelan Jalan. Padang: Universitas Andalas.

Utami, E. P. B. (2010) Perencanaan Geometrik Jalan Dan Rencana Anggaran Biaya Ruas Jalan Drono - Nganom Kecamatan Ngadirojo Kabupaten Wonogiri. Universitas Sebelas Maret.

Sukirman, S. (1999) Dasar-Dasar Perencanaan 